\title{
Formulation and In-Vitro Evaluation of Taste Masked Fast Disintegrating Tablets of Labetalol Hydrochloride by Wet Granulation Technique
}

\author{
SM Shahidulla1, Tayyaba Jeelani*1 \\ Deccan School of Pharmacy, Dar-Us-Salam, Aghapura, Hyderabad, Telangana- 500001-India
}

\begin{abstract}
Labetalol Hydrochloride is a $\beta$-blocker generally indicated for the treatment of hypertension, and it is extensively metabolized due to the hepatic metabolism. In the present work, an attempt was made to mask the taste by Solid Dispersion technique, with a formulation into Fast Disintegrating dosage form, using superdisintegrants such as Cross carmellose sodium (CCS), crospovidone (CP) and sodium starch glycolate (SSG). The complexes of Labetalol hydrochloride with HP- $\beta$-CD (1:3 ratio) were prepared by Co-precipitation method. Using the drug HP- $\beta$-CD complex, Fast Disintegrating tablets were prepared by Wet granulation Technique and evaluated for hardness, friability, weight variation, thickness, disintegrating time (DT), In-vitro dispersion time and dissolution rate. The results of Direct compression optimized formulation WG9 (Sodium Starch Glycolate $15 \mathrm{mg}$ and Starch paste $18 \mathrm{mg}$ ) has shown the \% Drug release of $99.97 \%$, In-vitro Dispersion time of 16 Secs respectively.
\end{abstract}

Keywords: Solid dispersions, fast disintegrating tablets, Labetalol, Crospovidone, Croscarmellose sodium and Sodium starch glycolate.

Article Info: Received 08 July 2019; Review Completed 19 Aug 2019; Accepted 22 Aug 2019; Available online 30 Aug 2019

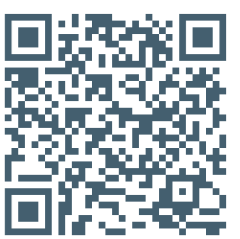

\section{Cite this article as:}

Shahidulla SM, Jeelani T, Formulation and In-Vitro Evaluation of Taste Masked Fast Disintegrating Tablets of Labetalol Hydrochloride by Wet Granulation Technique, Journal of Drug Delivery and Therapeutics. 2019; 9(4-A):442-449 http://dx.doi.org/10.22270/jddt.v9i4-A.3506

Tayyaba Jeelani, Deccan School of Pharmacy, Dar-Us-Salam, Aghapura, Hyderabad, Telangana- 500001-India

\section{INTRODUCTION:}

Oral route has been one of the most popular routes of drug delivery due to its ease of administration, patient compliance, least sterility constraints and flexible design of dosage forms. For many decades treatment of an acute disease or chronic illness has mostly accomplished by delivery of drugs to patients using conventional drug delivery system. Even today these conventional drug delivery systems are the primary pharmaceutical products commonly seen in the prescription. Conventional oral drug products are formulated to release the active principle immediately after oral administration to obtain rapid and complete systemic drug absorption. ${ }^{1}$

Difficulty in swallowing (dysphagia) is common among all age groups, especially in elderly, and is also seen in swallowing conventional tablets and capsules. The novel technology of fast-disintegrating dosage forms is known as fast dissolve, rapid dissolve, rapid melt and quick disintegrating tablets. A solid dosage form that dissolves or disintegrates quickly in the oral cavity, resulting in solution or suspension without the need for the administration of water, is known as an fast-disintegrating dosage form. ${ }^{2}$
Taste is one of the most important parameters governing patient compliance. Undesirable taste is one of several important formulation problems that are encountered with certain drugs. Taste masking is defined as a perceived reduction of an undesirable taste that would otherwise exist. ${ }^{3-6}$

Labetalol $\mathrm{HCl}$ is a blocker of both alpha- and beta-adrenergic receptors that is used as an antihypertensive agent. Labetalol is used parenterally for immediate reduction in blood pressure in severe hypertension or in hypertensive crises when considered an emergency, for the control of blood pressure in patients with pheochromocytoma and pregnant women with preeclampsia, and to produce controlled hypotension during anesthesia to reduce bleeding resulting from surgical procedures. Absorption Completely absorbed (100\%) from the gastrointestinal tract with peak plasma levels occurring 1 to 2 hours after oral administration. The absolute bioavailability of labetalol $\mathrm{HCl}$ is increased when administered with food.7-8

\section{MATERIALS AND METHODS:}

Labetalol $\mathrm{HCl}$ supplied by Pharma Train, HP-Betacyclo dextrin Purchased from Signet Chemicals Co. Ltd., (Mumbai, India), Crosspovidone was and Crosscarmellose sodium, was 
purchased from Yaroow chemicals and pharmaceuticals ( Mumbai , India) Sodium Starch Glycolate and MCC was obtained as a gift sample from Maple Biotech India pvt,Ltd (Pune , India), Talc , Mannitol, Magnesium Stearate Purchased from S.D. Fine Chem. Ltd.

\section{Drug polymer compatibility studies:}

\section{Fourier Transform Infrared Spectroscopy (FTIR):}

Ten milligrams of drug alone, mixture of drug and polymer were weighed and mixed properly with $\mathrm{KBr}$ uniformly. A small quantity of the powder was compressed into a thin semitransparent pellet by applying pressure. The IRspectrum of the pellet from $450-4500 \mathrm{~cm}^{-1}$. (Figure no. 1,2)

\section{Differential Scanning Calorimetric (DSC):}

Differential scanning calorimeter (DSC) was performed using Perkin Elmer instruments,

(Perkin Elmer DSC-7, Norway, USA.) to study the thermal behaviour of labetalol hydrochloride and mixture of drug and polymers. (Figure no. 3,4)

Preparation of Solid Dispersion by Co - Precipitation Method:

Drug was dissolved in ethanol at room temperature and polymer was dissolved in distilled water. Different molar ratios of Drug and polymer (1:1, 1:2 and 1:3) were taken The mixture was stirred at room temperature, for one hour and then slowly evaporated on a boiling water bath. The inclusion complex precipitated as a crystalline powder was pulverized and passed through sieve No. 80 and stored in a desiccator till free from any traces of the organic solvent.

Table no.1: Formulation codes for the Labetalol $\mathrm{HCl}$ solid dispersions

\begin{tabular}{|c|c|c|c|c|c|c|}
\hline \multirow{2}{*}{ Ingredients (mg) } & \multicolumn{6}{|c|}{ Formulation code } \\
\hline & SD1 & SD2 & SD3 & SD4 & SD5 & SD6 \\
\hline Labetalol HCl & 100 & 100 & 100 & 100 & 100 & 100 \\
\hline Beta cyclodextrine & 100 & 200 & 300 & - & - & - \\
\hline HP-Beta cyclodextrine & - & - & - & 100 & 200 & 300 \\
\hline
\end{tabular}

In both the Polymer's used HP-Betacyclodextrine > Betacyclodextrine

Drug: Polymer complex of SD6 (Drug: HP-Betacyclo dextrin $1: 3$ \& by Co-precipitate method) is having the better solubility enhancement. (Table no. 3, Figure no. 5)

Preparation of Labetalol $\mathrm{HCl}$ of fast disintegrating tablets by Wet granulation technique

All the powders were passed through \#80 mesh sieve. Required quantity of drug mixture (Solid dispersion) and excipients were mixed thoroughly. Mixture was then granulated using Starch paste and granules were made. Granules were dried at $40^{\circ} \mathrm{C}$ for about 15 min. After drying super disintegrants was added externally. Talc and magnesium stearate were added as glident and lubricant respectively. The tablet was compressed using $9 \mathrm{~mm}$ round flat punches to get tablets of $300 \mathrm{mg}$ weight on 10 station rotary tablet machine (CLIT).

Table no. 2. Formulation Design of Labetalol HCl using Wet Granulation Technique

\begin{tabular}{|c|c|c|c|c|c|c|c|c|c|c|}
\hline Ingredients (mg) & WG0 & WG1 & WG2 & WG3 & WG4 & WG5 & WG6 & WG7 & WG8 & WG9 \\
\hline $\begin{array}{c}\text { Labetalol+HP Betacyclodextrine } \\
\text { (SD6) }\end{array}$ & 200 & 200 & 200 & 200 & 200 & 200 & 200 & 200 & 200 & 200 \\
\hline Crospovidone & - & 5 & 10 & 15 & & & & & & \\
\hline Cross carmellose sodium & - & & & & 5 & 10 & 15 & & & \\
\hline Sodium starch glycolate & - & & & & & & & 5 & 10 & 15 \\
\hline Starch paste & 8 & 12 & 12 & 12 & 15 & 15 & 15 & 18 & 18 & 18 \\
\hline Mannitol & 84 & 75 & 70 & 65 & 72 & 67 & 62 & 69 & 64 & 59 \\
\hline Talc & 3 & 3 & 3 & 3 & 3 & 3 & 3 & 3 & 3 & 3 \\
\hline Magnesium stearate & 3 & 3 & 3 & 3 & 3 & 3 & 3 & 3 & 3 & 3 \\
\hline Pippermint flavor & 2 & 2 & 2 & 2 & 2 & 2 & 2 & 2 & 2 & 2 \\
\hline Total weight & 300 & 300 & 300 & 300 & 300 & 300 & 300 & 300 & 300 & 300 \\
\hline
\end{tabular}




\section{Pre Compression Parameters}

\section{Angle of Repose}

Angle of repose was determined using cylinder method. The blend was poured through a funnel that can be raised vertically until a maximum cone height (h) was obtained. Radius of the heap ( $\mathrm{r}$ ) was measured and the angle of repose (q) was calculated using the formula (Table no.4)

$$
\theta=\tan ^{-1}(r / h)
$$

\section{Bulk density:}

Bulk density of powdered blend was determined by pouring gently through a glass funnel into $50 \mathrm{ml}$ graduate $9 \mathrm{~d}$ cylinder. The volumes occupied by the samples were recorded. Bulk density was calculated as:

$$
\text { Bulk density }=\frac{\text { weight of sample in gram }}{\text { volume occupied by the sample }}
$$

\section{Tapped density:}

An accurately weighed sample of powder was carefully added to the cylinder with the aid of a funnel. Typically, the initial volume was noted, and the sample is then tapped (500, 750 or 1250 tapping) until no further reduction in volume is noted or the percentage of difference is not more than $2 \%$. A sufficient number of taps should be employed to assure reproducibility for the material in question. Volume was noted and taped density is calculated using following formula. 10

$$
\text { Tapped density }=\frac{\text { Wt. of sample in } \mathrm{gm}}{\text { Tapped volume }}
$$

\section{Compressibility Index :}

One of the important measures that can be obtained from bulk and tapped density determinations is the percent Compressibility or the Carr`s Index,I which is determined by the following equation. ${ }^{11}$

\section{$\mathrm{I}=$ Tapped density -Bulk Density/ Tapped density}

\section{Hausner`s Ratio:}

Hausner`s Ratio is defined as a ratio of a tapped density to bulk density. It is a measure of relative importance of interparticulate interactions. A Hausner ratio greater than 1.25 is considered to be an indication of poor flowability. ${ }^{11}$

Hausners Ratio $=$ Tapped Density $/$ Bulk denisty

\section{Evaluation of Post-Compression Parameters:}

\section{a. Weight variation test: 12}

Twenty tablets were selected randomly from each formulation, weighed individually and the average weight and $\%$ variation of weight was calculated. (Table no. 5)

\section{b. Thickness: 13}

Six tablets of each batch were selected and measured for thickness and diameter using the digital venire calipers. The extent to which the thickness of each tablet deviated from $\pm 5 \%$ of the standard value was determined.

\section{c. Hardness:}

Hardness was measured using the Monsanto hardness tester. Measure the pressure required to break diametrically placed matrix tablet, by a coiled spring.

\section{d. Friability test:}

The friability of the tablets was determined by using the Roche Friabilator. It is expressed in percentage (\%). Ten tablets were initially weighed ( $\left.\mathrm{W}_{\text {initial }}\right)$ and transferred into the friabilator. The friabilator was operated at $25 \mathrm{rpm}$ for four minutes. The tablets were weighed again $\left(\mathrm{W}_{\text {final }}\right)$. The percentage friability was then calculated using the equation

$$
\mathrm{F}=\left(\mathrm{W}_{\text {initial }}-\mathrm{W}_{\text {final }} \mathrm{x} 100\right) / \mathrm{W}_{\text {initial }} \%
$$

Friability of tablets less than $1 \%$ was considered acceptable. The friability was expressed as the loss of mass and was calculated as a percentage of the initial mass.

\section{e. Drug Content:}

10 Tablets were taken and powdered. Powder equivalent to one tablet was weighed accurately and allowed to dissolve in $10 \mathrm{ml}$ phosphate buffer and makeup the volume up to $100 \mathrm{ml}$. The solution was filtered; $1 \mathrm{ml}$ of filtrate was taken in $50 \mathrm{ml}$ of volumetric flask and diluted up to the mark with 6.8 phosphate buffer and analyzed spectrophotometrically at $305 \mathrm{~nm} .{ }^{14}$

\section{f. Wetting time and water absorption ratio:}

A piece of tissue paper folded twice was placed in a small Petri dish containing $6 \mathrm{ml}$ of water. A tablet was carefully placed on the surface of the tissue paper. The time required for water to reach the upper surface of the table was noted as the wetting time.

Water absorption ratio (R) was calculated using the formula:

$$
\mathrm{R}=100 \times\left[\mathrm{W}_{\mathrm{a}}-\mathrm{W}_{\mathrm{b}}\right] / \mathrm{W}_{\mathrm{b}}
$$

where, $\mathrm{W}_{\mathrm{a}}=$ weight of tablet after absorption, $\mathrm{W}_{\mathrm{b}}=$ weight of tablet before absorption.

\section{g. In-vitro disintegration time:}

The disintegration time for all formulations was carried out using a tablet disintegration test apparatus. Six tablets were placed individually in each tube of the disintegration test apparatus and the disks were placed. The water was maintained at a temperature of $37 \pm 2^{\circ} \mathrm{C}$ and the time taken for the entire tablet to disintegrate completely was noted.

h. In-vitro dispersion time: In-vitro dispersion time was measured by dropping a tablet in a measuring cylinder containing $6 \mathrm{ml}$ of simulated saliva fluid $\left(\mathrm{p}^{\mathrm{H}} 6.8\right)$. Three tablets from each formulation were randomly selected and in-vitro dispersion time was expressed in seconds.

\section{i. In-vitro drug release studies:}

In-vitro drug release studies were carried out using the USP XXIII Dissolution Apparatus II (Paddle Type) at $50 \mathrm{rpm}$. The drug release profile was studied in $900 \mathrm{ml}$ of phosphate buffer pH-6.8 as dissolution medium. Temperature was maintained at $37 \pm 0.5^{\circ} \mathrm{C}$. Aliquots of $5 \mathrm{ml}$ of dissolution medium were withdrawn at specific time intervals at every five minutes and filtered. The amount of drug released was determined by the UV-Visible spectrophotometer at $305 \mathrm{~nm}$ and concentration of drug was determined from standard calibration curve. ${ }^{16}$ (Table no. 6 Fig no. 6)

\section{g. Stability studies:}

Stability studies were performed at a temperature of $25 \pm 2{ }^{\circ} \mathrm{C}$ / $65 \pm 5 \% \mathrm{RH} \& 40 \pm 2^{\circ} \mathrm{C} / 75 \pm 5 \% \mathrm{RH}$, over a period of three months (90 days) on the promising FDT of Labetalol $\mathrm{HCl}$ formulation (Table no. 8) 
RESULTS AND DISCUSSION:

FT-IR Spectroscopic Analysis:

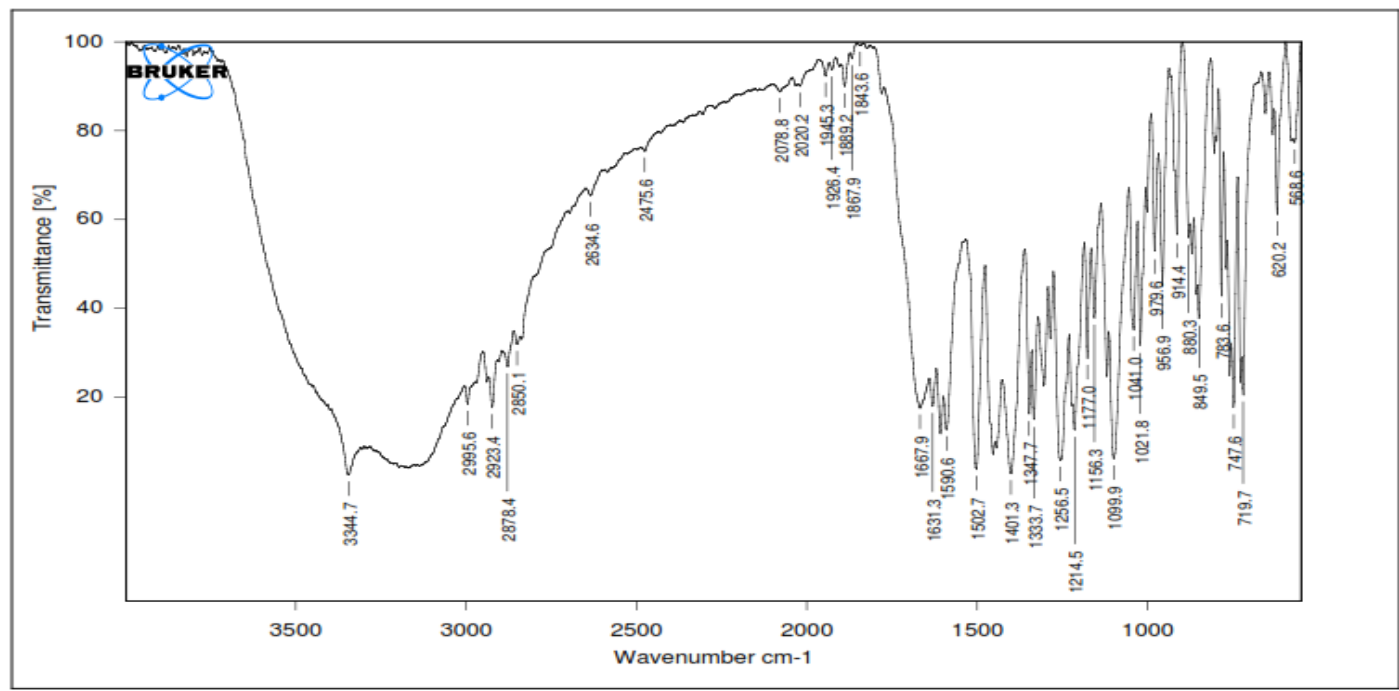

Fig 1 FTIR graph for Labetalol HCl (Pure Drug)

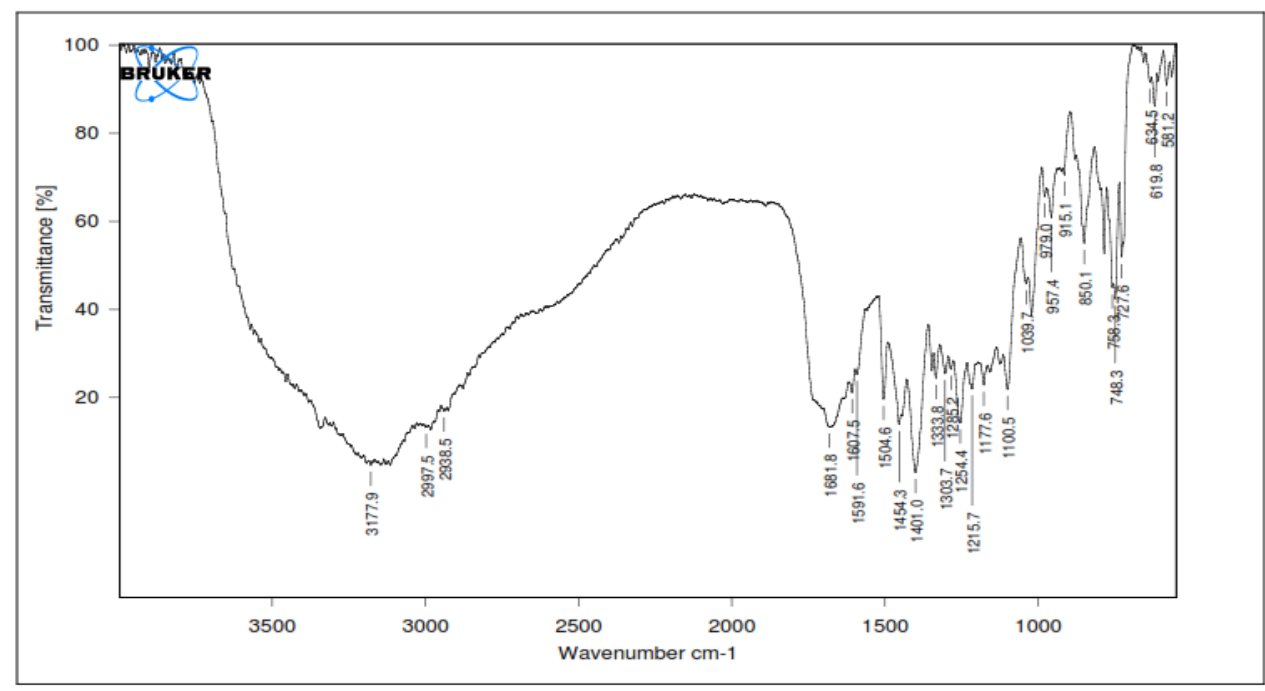

Fig: 2 FTIR graph for Labetalol HCl + Excipients

Differential Scanning Calorimetry (DSC) Studies

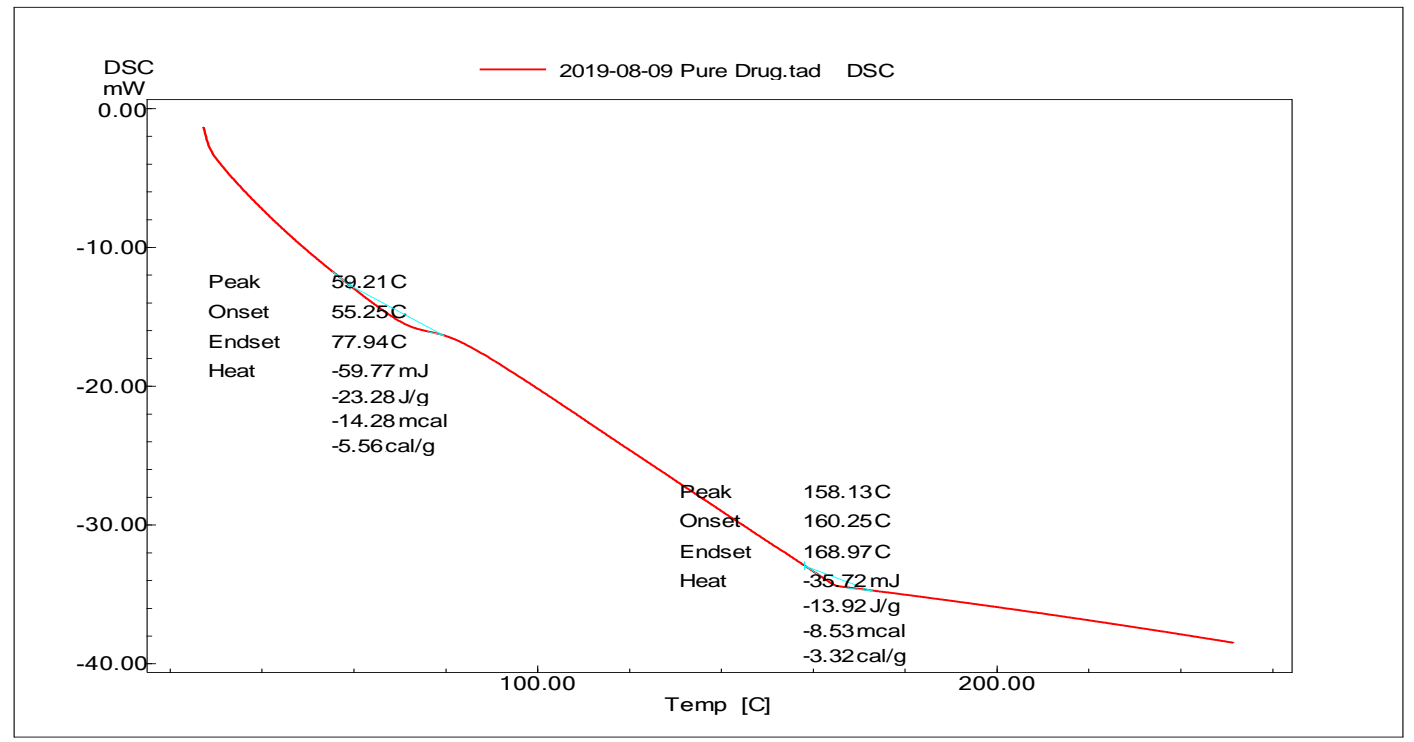

Fig :3 DSC of Pure Drug 


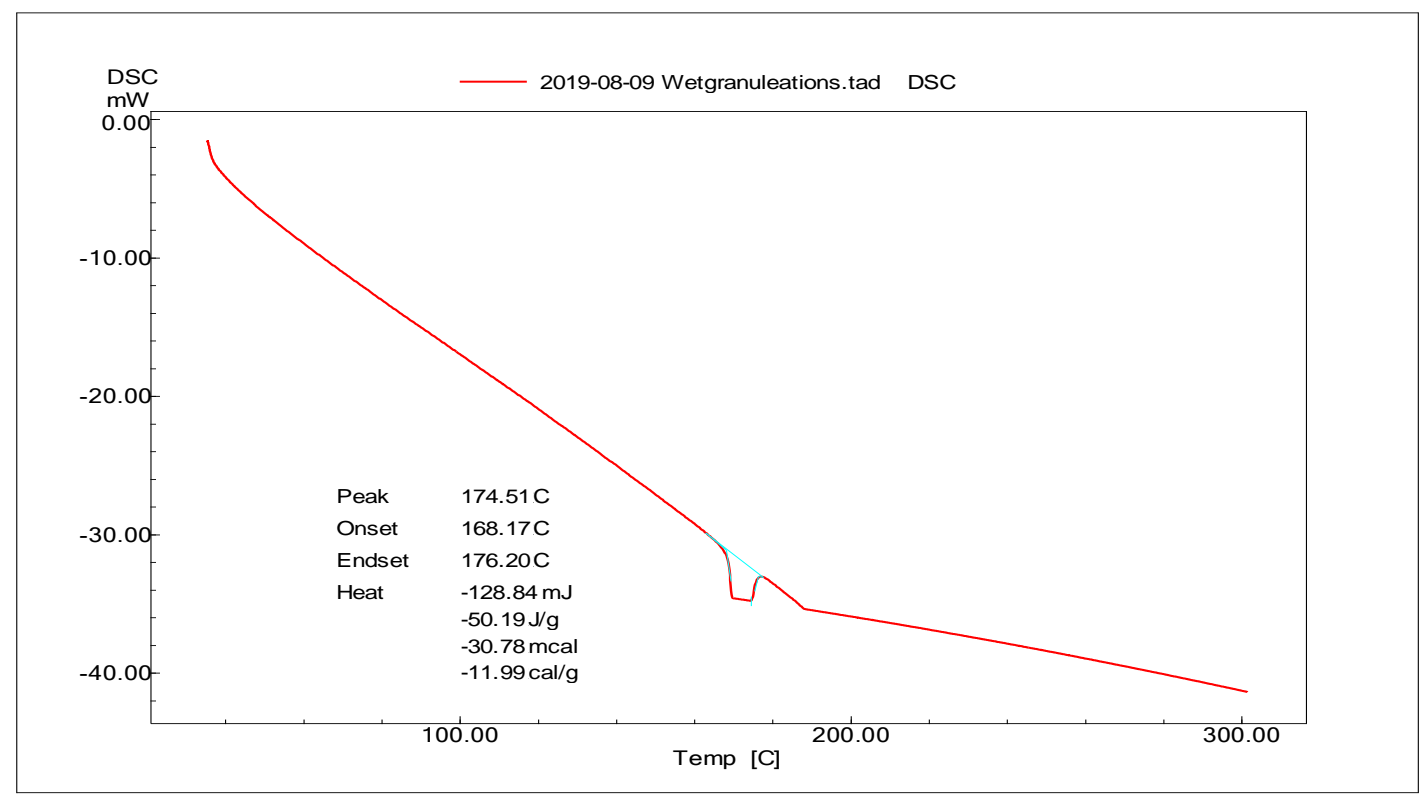

Fig:4 DSC of Optimized Formulation (WG9)

DSC thermogram of untreated/ pure drug shows an endothermic peak at $158^{\circ} \mathrm{C}$, which is related to its melting point. Physical mixture of excipients and the drug of the Optimized Formulation WG9 showed endothermic peaks at $174.51^{\circ} \mathrm{C}$. It was found that there are no new peaks appeared in the thermogram of the drug and excipients. Thus, there is no interaction between the drug and the tablet excipients, was observed. However, there is a very slight shift in the drug peak and this might be due to a reduction of the purity of components by mixing.

Table :3 Dissolution data of Labetalol Solid dispersions

\begin{tabular}{|c|c|c|c|c|c|c|}
\hline Time(min) & SD1 & SD2 & SD3 & SD4 & SD5 & SD6 \\
\hline 0 & 0 & 0 & 0 & 0 & 0 & 0 \\
\hline 5 & $8.91 \pm 0.052$ & $15.02 \pm 0.054$ & $12.76 \pm 0.068$ & $9.28 \pm 0.01$ & $15.43 \pm 0.012$ & $26.65 \pm 0.025$ \\
\hline 10 & $11.55 \pm 0.020$ & $18.85 \pm 0.056$ & $18.28 \pm 0.011$ & $12.26 \pm 0.065$ & $20.68 \pm 0.0 .019$ & $35.05 \pm 0.043$ \\
\hline 15 & $15.56 \pm 0.078$ & $21.9 \pm 0.067$ & $24.36 \pm 0.025$ & $16.15 \pm 0.087$ & $26.97 \pm 0.053$ & $46.15 \pm 0.044$ \\
\hline 20 & $19.34 \pm 0.049$ & $28.22 \pm 0.078$ & $31.16 \pm 0.045$ & $20.86 \pm 0.054$ & $32.87 \pm 0.045$ & $56.35 \pm 0.062$ \\
\hline 30 & $23.19 \pm 0.067$ & $34.8 \pm 0.023$ & $37.88 \pm 0.034$ & $24.31 \pm 0.054$ & $39.45 \pm 0.054$ & $67.6 \pm 0.068$ \\
\hline 40 & $27.75 \pm 0.087$ & $42.92 \pm 0.034$ & $44.49 \pm 0.053$ & $28.4 \pm 0.053$ & $47.58 \pm 0.052$ & $82.6 \pm 0.079$ \\
\hline 50 & $29.47 \pm 0.067$ & $45.3 \pm 0.051$ & $48.44 \pm 0.791$ & $30.46 \pm 0.078$ & $50.76 \pm 0.088$ & $86.9 \pm 0.062$ \\
\hline 60 & $31.26 \pm 0.003$ & $46.87 \pm 0.33$ & $51.28 \pm 0.34$ & $32.09 \pm 0.04$ & $54.38 \pm 0.02$ & $93.12 \pm 0.022$ \\
\hline
\end{tabular}

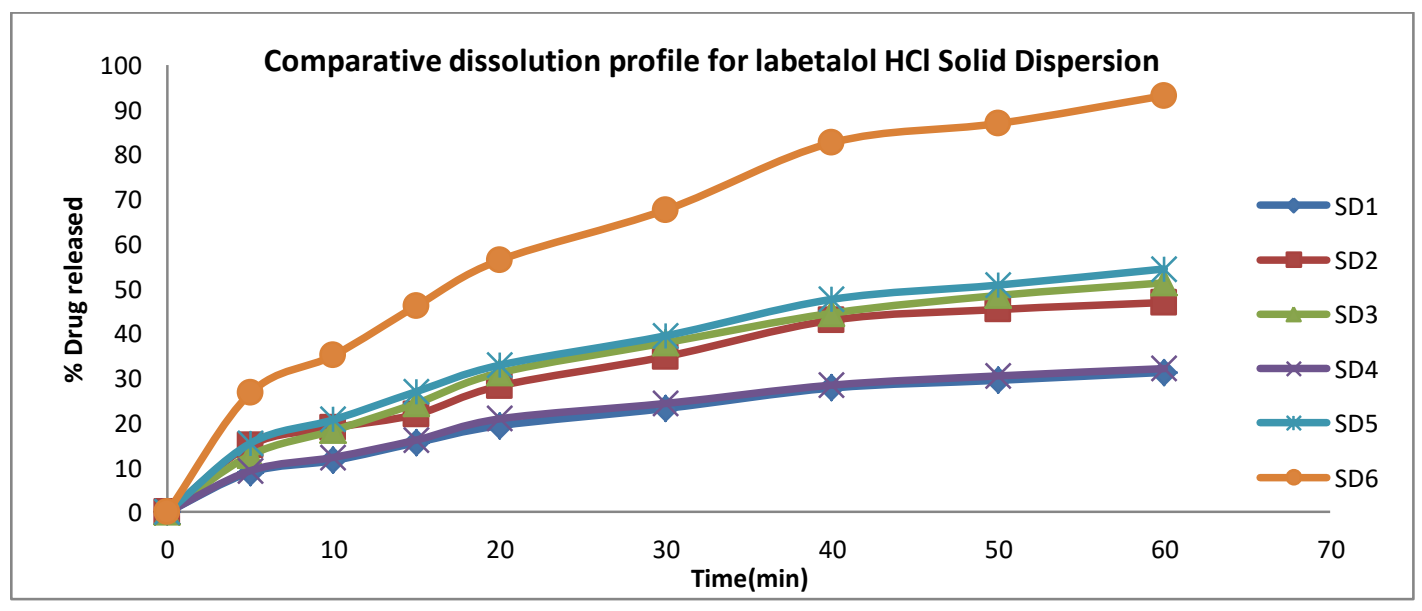

Fig 5: Comparative dissolution profile for labetalol HCl Solid Dispersion 
Table 4: Pre compression studies of Labetalol $\mathrm{HCl}$ fast disintegrating tablets (Wet Granulation Technique)

\begin{tabular}{|c|c|c|c|c|c|}
\hline $\begin{array}{c}\text { Formulation } \\
\text { Code }\end{array}$ & Bulk density & $\begin{array}{c}\text { Tapped } \\
\text { density }\end{array}$ & Cars index & $\begin{array}{c}\text { Hausners } \\
\text { ratio }\end{array}$ & $\begin{array}{c}\text { Angle of } \\
\text { repose ( }{ }^{\circ} \text { ) }\end{array}$ \\
\hline WG0 & $0.26 \pm 0.07$ & $0.30 \pm 0.06$ & $13.84 \pm 0.04$ & $1.16 \pm 0.04$ & $33.72 \pm 0.03$ \\
\hline WG1 & $0.28 \pm 0.09$ & $0.32 \pm 0.09$ & $12.95 \pm 0.13$ & $1.15 \pm 0.11$ & $32.62 \pm 0.15$ \\
\hline WG2 & $0.29 \pm 0.12$ & $0.31 \pm 0.11$ & $8.29 \pm 0 . `$ & $1.09 \pm 0.12$ & $29.47 \pm 0.18$ \\
\hline WG3 & $0.29 \pm 0.14$ & $0.31 \pm 0.12$ & $4.90 \pm 0.16$ & $1.05 \pm 0.15$ & $25.58 \pm 0.14$ \\
\hline WG4 & $0.32 \pm 0.15$ & $0.34 \pm 0.13$ & $5.66 \pm 0.18$ & $1.06 \pm 0.16$ & $26.77 \pm 0.17$ \\
\hline WG5 & $0.31 \pm 0.17$ & $0.34 \pm 0.14$ & $7.99 \pm 0.14$ & $1.09 \pm 0.20$ & $28.47 \pm 0.19$ \\
\hline WG6 & $0.32 \pm 0.18$ & $0.35 \pm 0.17$ & $7.79 \pm 0.12$ & $1.08 \pm 0.19$ & $27.17 \pm 0.23$ \\
\hline WG7 & $0.30 \pm 0.16$ & $0.32 \pm 0.18$ & $8.83 \pm 0.16$ & $1.10 \pm 0.16$ & $29.58 \pm 0.22$ \\
\hline WG8 & $0.29 \pm 0.15$ & $0.32 \pm 0.16$ & $9.70 \pm 0.17$ & $1.11 \pm 0.14$ & $30.11 \pm 0.15$ \\
\hline WG9 & $\mathbf{0 . 2 8} \pm 0.08$ & $\mathbf{0 . 3 2} \pm 0.09$ & $\mathbf{1 0 . 5 2} \pm 0.10$ & $\mathbf{1 . 1 2} \pm 0.18$ & $\mathbf{3 1 . 4 2} \pm 0.11$ \\
\hline
\end{tabular}

Table: 5 Post compression studies of Labetalol HCl fast disintegrating tablets (Wet Granulation Technique)

\begin{tabular}{|c|c|c|c|c|c|c|c|c|}
\hline $\begin{array}{l}\text { Formulation } \\
\text { Code }\end{array}$ & $\begin{array}{l}\text { \% weight } \\
\text { variation }\end{array}$ & $\begin{array}{c}\text { Thickness } \\
\text { (mm) }\end{array}$ & $\begin{array}{l}\text { Hardness } \\
\left(\mathrm{Kg} / \mathrm{cm}^{2}\right)\end{array}$ & $\begin{array}{c}\% \\
\text { friability }\end{array}$ & $\begin{array}{c}\text { Disintegration } \\
\text { time (Sec) }\end{array}$ & $\begin{array}{c}\text { In-vitro } \\
\text { Dispersion } \\
\text { time (Sec) }\end{array}$ & $\begin{array}{c}\text { Water } \\
\text { absorption } \\
\text { ratio } \\
\end{array}$ & $\begin{array}{l}\text { \% Drug } \\
\text { Content }\end{array}$ \\
\hline WG0 & 293.2 & $3.59 \pm 0.10$ & $2.5 \pm 0.20$ & $0.45 \pm 0.05$ & $62.54 \pm 0.11$ & $58.39 \pm 0.10$ & $62.48 \pm 0.23$ & $101.42 \pm 0.18$ \\
\hline WG1 & 300.5 & $4.17 \pm 0.17$ & $3.2 \pm 0.05$ & $0.38 \pm 0.15$ & $56.49 \pm 0.16$ & $49.58 \pm 0.14$ & $73.58 \pm 0.31$ & $99.86 \pm 0.15$ \\
\hline WG2 & 301.4 & $4.12 \pm 0.25$ & $3.4 \pm 0.11$ & $0.28 \pm 0.11$ & $42.47 \pm 0.21$ & $35.39 \pm 0.17$ & $79.68 \pm 0.29$ & $99.35 \pm 0.23$ \\
\hline WG3 & 298.9 & $4.08 \pm 0.10$ & $3.5 \pm 0.15$ & $0.51 \pm 0.15$ & $39.59 \pm 0.29$ & $34.96 \pm 0.20$ & $76.4 \pm 0.19$ & $100.83 \pm 0.31$ \\
\hline WG4 & 299.1 & $4.18 \pm 0.17$ & $3.3 \pm 0.15$ & $0.37 \pm 0.13$ & $41.59 \pm 0.28$ & $40.87 \pm 0.19$ & $89.57 \pm 016$ & $100.43 \pm 0.49$ \\
\hline WG6 & 299.4 & $4.16 \pm 0.11$ & $3.5 \pm 0.10$ & $0.28 \pm 0.09$ & $30.59 \pm 0.42$ & $24.51 \pm 0.29$ & $92.48 \pm 0.16$ & $100.34 \pm 0.52$ \\
\hline WG7 & 298.1 & $4.12 \pm 0.05$ & $3.5 \pm 0.10$ & $0.36 \pm 0.06$ & $28.49 \pm 0.17$ & $21.43 \pm 0.25$ & $87.48 \pm 0.15$ & $99.38 \pm 0.41$ \\
\hline WG8 & 302.4 & $4.19 \pm 0.10$ & $3.1 \pm 0.10$ & $0.34 \pm 0.10$ & $29.51 \pm 0.22$ & $19.39 \pm 0.20$ & $88.39 \pm 0.22$ & $99.51 \pm 0.53$ \\
\hline WG9 & 299.5 & $4.07 \pm 0.05$ & $3.5 \pm 0.10$ & $0.36 \pm 0.11$ & $22.94 \pm 0.19$ & $16.49 \pm 0.18$ & $85.39 \pm 0.10$ & $99.61 \pm 0.33$ \\
\hline
\end{tabular}

Table :6 Dissolution data of various fast disintegrating tablets of Labetalol HCl (Wet Granulation Technique)

\begin{tabular}{|c|c|c|c|c|c|c|c|c|c|c|}
\hline $\begin{array}{l}\text { Time } \\
\text { (min) }\end{array}$ & WGO & WG1 & WG2 & WG3 & WG4 & WG5 & WG6 & WG7 & WG8 & WG9 \\
\hline 0 & 0 & 0 & 0 & 0 & 0 & $\mathbf{0}$ & 0 & 0 & 0 & 0 \\
\hline 5 & $\begin{array}{c}2.98 \pm 0.1 \\
2 \\
\end{array}$ & $\begin{array}{c}30.29 \pm 0 . \\
15\end{array}$ & $\begin{array}{c}32.94 \pm 0 . \\
20\end{array}$ & $\begin{array}{c}32.19 \pm 0 . \\
12\end{array}$ & $\begin{array}{c}31.84 \pm 0 . \\
29\end{array}$ & $\begin{array}{c}42.98 \pm 0 . \\
21 \\
\end{array}$ & $\begin{array}{c}43.29 \pm 0 . \\
29\end{array}$ & $\begin{array}{c}35.38 \pm 0 . \\
30\end{array}$ & $\begin{array}{c}39.29 \pm 0 . \\
21\end{array}$ & $\begin{array}{c}43.19 \pm 0 . \\
24\end{array}$ \\
\hline 10 & $\begin{array}{c}6.75 \pm 0.0 \\
9\end{array}$ & $\begin{array}{c}47.28 \pm 0 . \\
19\end{array}$ & $\begin{array}{c}54.27 \pm 0 \\
22\end{array}$ & $\begin{array}{c}63.86 \pm 0 \\
19\end{array}$ & $\begin{array}{c}63.29 \pm 0 . \\
32\end{array}$ & $\begin{array}{c}76.37 \pm 0 \\
29\end{array}$ & $\begin{array}{c}73.49 \pm 0 \\
27\end{array}$ & $\begin{array}{c}54.12 \pm 0 . \\
29\end{array}$ & $\begin{array}{c}71.39 \pm 0 . \\
29\end{array}$ & $\begin{array}{c}75.47 \pm 0 . \\
29\end{array}$ \\
\hline 15 & $\begin{array}{c}8.19 \pm 0.1 \\
2 \\
\end{array}$ & $\begin{array}{c}71.39 \pm 0 . \\
20 \\
\end{array}$ & $\begin{array}{c}77.47 \pm 0 \\
19 \\
\end{array}$ & $\begin{array}{c}87.97 \pm 0 . \\
21\end{array}$ & $\begin{array}{c}87.46 \pm 0 . \\
30\end{array}$ & $\begin{array}{c}99.71 \pm 0 . \\
19 \\
\end{array}$ & $\begin{array}{c}93.74 \pm 0 . \\
20\end{array}$ & $\begin{array}{c}74.25 \pm 0 . \\
21 \\
\end{array}$ & $\begin{array}{c}92.38 \pm 0 . \\
20\end{array}$ & $\begin{array}{c}99.97 \pm 0 . \\
16\end{array}$ \\
\hline 20 & $\begin{array}{c}10.92 \pm 0 \\
15\end{array}$ & $\begin{array}{c}88.27 \pm 0 \\
22\end{array}$ & $\begin{array}{c}92.46 \pm 0 \\
18\end{array}$ & $\begin{array}{c}99.46 \pm 0 \\
18\end{array}$ & $\begin{array}{c}98.46 \pm 0 \\
16\end{array}$ & $\begin{array}{c}99.70 \pm 0 \\
16\end{array}$ & $\begin{array}{c}99.96 \pm 0 \\
19\end{array}$ & $\begin{array}{c}91.38 \pm 0 \\
19\end{array}$ & $\begin{array}{c}99.51 \pm 0 . \\
17\end{array}$ & $\begin{array}{c}99.96 \pm 0 . \\
16\end{array}$ \\
\hline 25 & $\begin{array}{c}13.05 \pm 0 \\
08\end{array}$ & $\begin{array}{c}99.31 \pm 0 . \\
30\end{array}$ & $\begin{array}{c}99.21 \pm 0 . \\
21\end{array}$ & $\begin{array}{c}99.45 \pm 0 \\
18 \\
\end{array}$ & $\begin{array}{c}99.93 \pm 0 \\
11 \\
\end{array}$ & $\begin{array}{c}99.69 \pm 0 . \\
17\end{array}$ & $\begin{array}{l}99.95 \pm 0 . \\
18\end{array}$ & $\begin{array}{c}99.73 \pm 0 . \\
15 \\
\end{array}$ & $\begin{array}{c}99.50 \pm 0 . \\
16 \\
\end{array}$ & $\begin{array}{c}99.95 \pm 0 . \\
16\end{array}$ \\
\hline 30 & $\begin{array}{c}16.95 \pm 0 \\
17\end{array}$ & $\begin{array}{c}99.30 \pm 0 . \\
34\end{array}$ & $\begin{array}{c}99.19 \pm 0 . \\
21\end{array}$ & $\begin{array}{c}99.44 \pm 0 . \\
18\end{array}$ & $\begin{array}{c}99.92 \pm 0 \\
11\end{array}$ & $\begin{array}{c}99.70 \pm 0 . \\
16\end{array}$ & $\begin{array}{c}99.94 \pm 0 . \\
19\end{array}$ & $\begin{array}{c}99.72 \pm 0 . \\
15\end{array}$ & $\begin{array}{c}99.48 \pm 0 . \\
17\end{array}$ & $\begin{array}{c}99.97 \pm 0 \\
16\end{array}$ \\
\hline
\end{tabular}



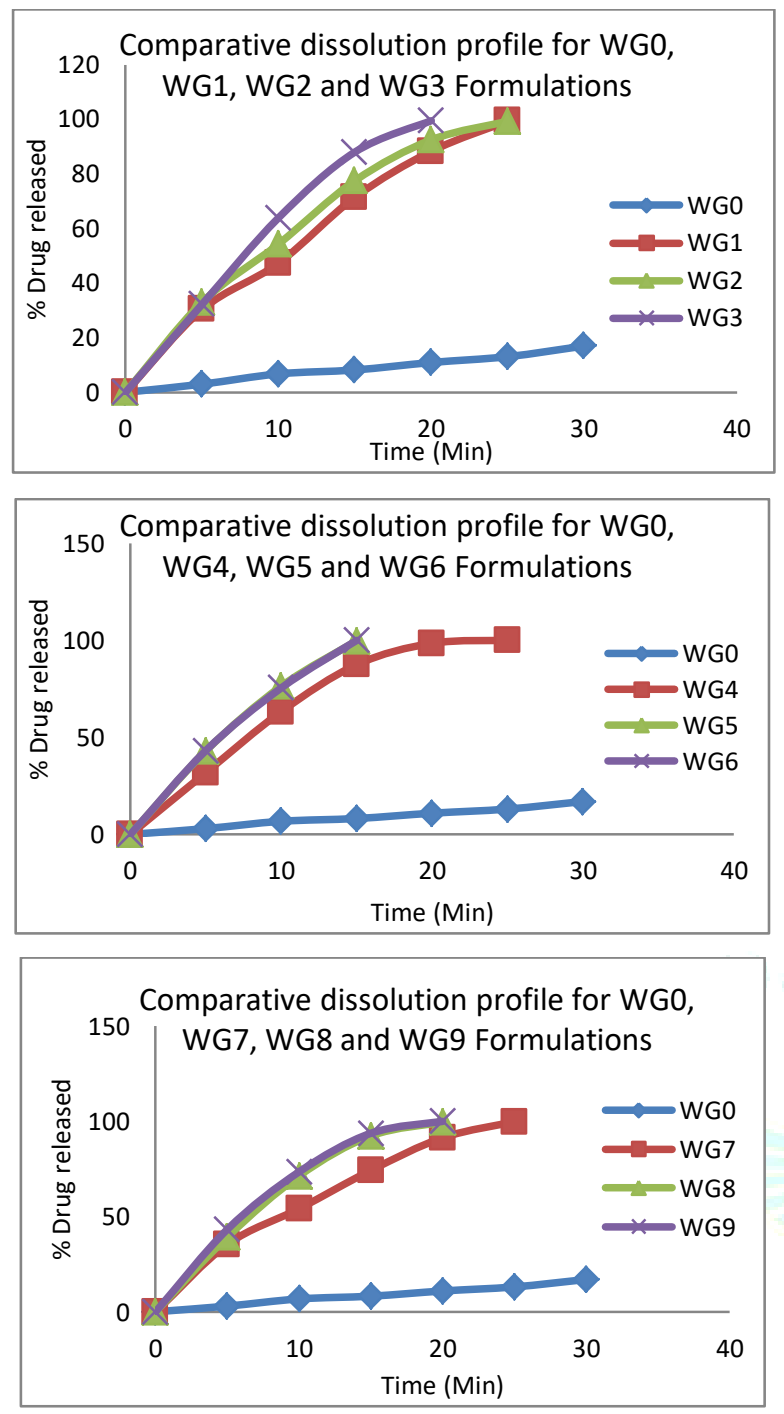

Fig: 6 Comparative dissolution profile
Table :7 Comparative dissolution profile for Marketed formulation (Trandate) and WG9

\begin{tabular}{|c|c|c|}
\hline Time(min) & Marketed formulation & WG9 \\
\hline 0 & 0 & 0 \\
\hline 5 & $23.21 \pm 0.21$ & $\mathbf{4 3 . 1 9} \pm 0.20$ \\
\hline 10 & $42.83 \pm 0.19$ & $\mathbf{7 5 . 4 7} \pm 0.16$ \\
\hline 15 & $64.53 \pm 0.26$ & $\mathbf{9 9 . 9 2} \pm 0.18$ \\
\hline 20 & $79.32 \pm 0.22$ & $99.96 \pm 0.19$ \\
\hline 25 & $91.43 \pm 0.19$ & $99.95 \pm 19$ \\
\hline 30 & $99.65 \pm 0.18$ & $99.93 \pm 17$ \\
\hline
\end{tabular}

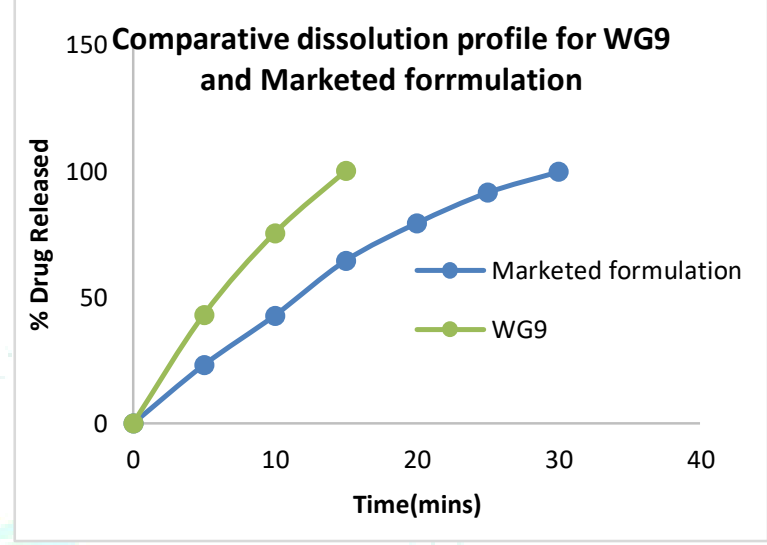

Fig: 7 Comparative dissolution profile for WG9 and Marketed forrmulation

Stability studies: There is no change in drug content and $\%$ drug release for the period of 3 months, so it is continued for the next three months as per ICH guidelines for stability studies.

Table :8 Stability studies for optimized formulation WG9

\begin{tabular}{|l|c|c|c|c|}
\hline \multicolumn{1}{|c|}{$\begin{array}{c}\text { Formulation } \\
\text { Code }\end{array}$} & $\begin{array}{c}\text { In-vitro } \\
\text { Dispersion } \\
\text { time (Sec) }\end{array}$ & \multirow{2}{*}{$\begin{array}{l}\text { \% Drug } \\
\text { Content }\end{array}$} & & \multicolumn{2}{c|}{ \% Drug released } \\
\cline { 4 - 5 } & & & $\begin{array}{c}\mathbf{2 5 \pm 2} \mathbf{C} / \\
\mathbf{6 5 \pm 5 \%} \mathbf{R H}\end{array}$ & $\begin{array}{c}\mathbf{4 0 \pm 2} \mathbf{C} / \\
\mathbf{7 5} \pm \mathbf{5 \%} \mathbf{R H}\end{array}$ \\
\hline Fisrt day & $16.49 \pm 0.14$ & $99.61 \pm 0.11$ & $99.61 \pm 0.19$ & $99.61 \pm 0.20$ \\
\hline 30 days & $16.51 \pm 0.11$ & $99.41 \pm 0.23$ & $99.53 \pm 0.16$ & $99.59 \pm 0.18$ \\
\hline 60 days & $16.33 \pm 0.15$ & $99.24 \pm 0.19$ & $99.42 \pm 0.27$ & $99.52 \pm 0.29$ \\
\hline 90 days & $16.22 \pm 0.14$ & $99.06 \pm 0.27$ & $99.32 \pm 0.30$ & $99.45 \pm 0.22$ \\
\hline
\end{tabular}

\section{CONCLUSION}

For this study Fast disintegrating tablet are prepared by using Labetalol $\mathrm{HCl}$ as a model drug is used as AntiHypertensive. From the Solid Dispersion studies it can be concluded that In vitro dissolution studies for solid dispersion has been performed and the results shows that SD6 shows the greater drug release than compared to the other dispersions. SD6 containing 1: 3 concentration of Drug and HP Beta cyclodextrin shows the best suitable Solid dispersion to be used for taste masking and to enhace the ensolubility of the drug.
Labetalol HCl Fast Disintegrating Tablets was successfully prepared by using Direct compression Technique. Evaluation parameters like Weight variation, Thickness, Hardness, Friability, and drug content indicate that values were within permissible limit for all formulations. In vitro drug release study was carried out Fast disintegrating tablets prepared by Wet Granulation technique and based on the results; WG9(Containing $15 \mathrm{mg}$ of Sodium Starch Glycolate) showed the \% Drug release of $99.97 \%$, In-vitro Dispersion time of 16 Secs respectively was identified as the best formulation among all the other formulations. The Sodium Starch Glycolate used formulation has shown better 
release profile than compared with other formulations by Direct Compression Technique. The optimized formulation follows first order kinetics with regression coefficient WG9 0.998 respectively. Stability studies indicate that the formulated oral disintegrating tablets are stable for a period of 3 months under two different conditions.

Conflict of interest: The authors declare no conflict of interest.

ACKNOWLEDGEMENT: The author is thankful to the Deccan School of pharmacy

Nampally Aghrapura, Hyderabad, for providing necessary facilities to carry out this work.

\section{REFERENCES}

1. D.M.Brahmankar, Sunil B. Jaiswal, Biopharmaceutics and Pharmakokinetics, A Treatise, $1^{\text {st }}$ ed, Vallabh Prakasan, Delhi, 2005; 27,29-30.

2. Devarajan, Padma V, Gore SP. Melt-in-mouth tabletsinnovative oral drug delivery systems. Express Pharma Pulse. 2000; 7(1): 16-18

3. Christian Leuner., Jennifer Dressmann., Improving drug solubility for oral delivery using solid dispersions. European Journal of Pharmaceutics and Biopharmaceutics, 2000, 50, 47 48

4. James Swarbrick., James C Boylan., Encyclopedia of Pharmaceutical Technology, $2^{\text {nd }}$ edition, Vol-1:8:135-139.

5. J.Senthil, S. Shanmugam, T. Vetrichelvan, International journal of pharma and bioscience,2011, 2, 338-344.

6. Leon Shargel., Andrew B.C, Applied Biopharmaceutics and Pharmacokinetics, Appleton-Century-Crofts, 4th Ed, 1985; 134-142.

7. Anonymous, www.drugs.com, detail drug profile information.
8. Anonymous, Indian Pharmacopoeia, Published by the Controller of Publication, Govt. of India, Ministry of Health and Family Welfare, New Delhi, Vol.1,2,3, 2007, 1045

9. Manoj Varma Gottumukkala, Senthil Kumar K , Dr. Mohammed Gulzar Ahmed and Krishna K, An Approach To Formulate And Evaluate Labetalol As Fast Dissolving Tablets, World Journal of Pharmaceutical Research, Volume 3, Issue 6, 735-754.

10. Raghavendra Kumar Gunda, Prasada Rao Manchineni, MV Kiran Kumar, Design, development and evaluation of labetalol $\mathrm{Hcl}$ gastro retentive floating tablets, International Journal of Advances in Pharmacy and Biotechnology, 2018, 4(2)13-24.

11. Nagar Bhanu, Sheorey Sonali, Agrawal Vipul, Shah Nirmal, Shah Jainam, Formulation And Evaluation Of Orodispersible Labetalol Tablet For Hypertensive Crisis, Journal Of Drug Delivery \& Therapeutics; 2013, 3(6), 106-112.

12. Nagadani.Swarnalatha, Vidyavathi Maravajhala, Formulation and evaluation of taste masked oraldisintegrating tablets of loratadine, International journal of research in pharmacy and chemistry, , 2017, 7(3), 353-359

13. Saleh Abd El Rasoul, Gamal A. Shazly, Propafenone $\mathrm{HCl}$ fast dissolving tablets containing subliming agent prepared by direct compression method, Saudi Pharmaceutical Journal, 2017:2(2);562-572.

14. Pankaj V. Gore, Swati Jagdale, Formulation and development of fast disintegrating tablet of Nortriptyline hydrochloride. Journal of Chemical and Pharmaceutical Research, 2015, $7(6): 138-146$.

15. Deepak Sharma, Mankaran Singh, Dinesh Kumar, Gurmeet Singh, Formulation Development and Evaluation of Fast Disintegrating Tablet of Cetirizine Hydrochloride: A Novel Drug Delivery for Pediatrics and Geriatrics; Journal of Pharmaceutics Volume 1; 2014,1(2):235-242.

16. Niyaz Kavugoli, Ravikumar, Narayanaswamy VB, Formulation and Evaluation of Controlled Release Matrix Tablets of Labetalol $\mathrm{HCl}$; Asian Journal of Pharmaceutical Research; 2016; 6(2):978-982. 